\title{
Gamma-Interferon-like Immunoreactivity in Axotomized Rat Motor Neurons
}

\author{
Tomas Olsson, ${ }^{1}$ Krister Kristensson, ${ }^{2}$ Åke Ljungdahl, ${ }^{1}$ Jan Maehlen, ${ }^{2}$ Rickard Holmdahl, ${ }^{3}$ and Lars Klareskog ${ }^{3}$ \\ Departments of ${ }^{1}$ Neurology, and ${ }^{2}$ Cellular and Neuropathology, Karolinska Institutet, Huddinge, and ${ }^{3}$ Department of \\ Medical and Physiological Chemistry, Uppsala University, Uppsala, Sweden
}

\begin{abstract}
Major histocompatibility complex (MHC) encoded antigens, absent or present at only low levels in normal brain tissue, are induced locally around axotomized motor neurons. We here report that immunoreactivity for the potent MHC-inducing factor, gamma-interferon (IFN- $\gamma$ ), appears in the cytoplasm of such neurons. Rat facial nerves were interrupted (crushed or cut), and later, at various intervals, cryosections from the facial nuclei were subjected to immunohistochemistry with monoclonal antibodies reacting with IFN- $\gamma$ and MHC antigens. IFN- $\boldsymbol{\gamma}$-like immunoreactivity appeared briskly in the cytoplasm of the axotomized motor neurons. The immunoreactivity subsided after a nerve crush as the target muscles were reinnervated, but persisted when nerve regeneration was prevented after a nerve cut. These results point to a role for nerve cell-derived IFN- $\gamma$-like molecules in eliciting the neural cell responses to axotomy.
\end{abstract}

Cytokines, i.e., soluble molecules that serve regulatory functions in the immune system, have been found in the CNS. One example of this is interleukin-1, which appears during restricted periods of the brain development and after brain trauma (Giulian et al., 1988). Recently, the occurrence of the cytokine gamma-interferon (IFN- $\gamma$ ) in localized nerve fiber tracts has been suggested in an immunohistochemical study (Ljungdahl et al., 1989). Moreover, an early gene induced by nerve growth factor in cultured PC1 2 cells shows homology to IFN- $\gamma$, and this gene is also expressed in the developing spinal cord (Tirone and Shooter, 1989).

IFN- $\gamma$ in the immune system is produced by activated lymphoid cells and regulates the function of its target cells (Trinchieri and Perussia, 1985; Sandvig et al., 1987). It induces expression of major histocompatibility complex (MHC) coded antigens (Wallach et al., 1982; Nakamura et al., 1984; Rosa and Fellous, 1984; Wong et al., 1984; Skoskiewicz et al., 1985), which play a crucial role in cellular immune recognition. In the normal nervous system, no or only low levels of these $\mathrm{MHC}$ antigens have been detected, but they can be induced during immunological reactions (Lampson, 1987). Evidence for a local regulatory control of $\mathrm{MHC}$ expression in the $\mathrm{CNS}$ is suggested

\footnotetext{
Received Feb. 7, 1989; revised May 1, 1989; accepted May 5, 1989.

This work was supported by grants from the Swedish Medical Research Council (project numbers 07488 and 04480 ). We thank Åsa Wildte for technical and IngaLisa Wallgren for secretarial assistance.

Correspondence should be addressed to Dr. T. Olsson, Department of Neurology, Huddinge University Hospital, S-141 86 Huddinge, Sweden.

Copyright (C) 1989 Society for Neuroscience $0270-6474 / 89 / 113870-06 \$ 02.00 / 0$
}

by our recent observation of a transient induction of $\mathrm{MHC}$ antigens in areas of axotomized motor neurons (Maehlen et al., 1988, 1989a). In accordance with this, we here report a brisk induction of IFN- $\gamma$-like immunoreactivity in the cytoplasm of axotomized motor neurons.

\section{Materials and Methods}

Twenty-four Sprague-Dawley rats (Alab, Stockholm) were anesthetized with ether and subjected to an axotomy of their left facial nerves, approximately $1 \mathrm{~mm}$ distal to the exit from the stylomastoid foramen. A small branch of the nerve to the ear muscles was included in the axotomy. In 12 rats the nerve was crushed with a jewellers forceps for 20 sec, and in the rest the nerve was cut with a pair of scissors. The success of the operations and later signs of reinnervation were checked by daily observation of the movements of the whiskers (Olsson et al., 1978). Rats with a crush lesion of the facial nerve regained the movements of their left whisker regularly on day 12 postoperation (p.o.), while rats with a cut lesion did not regain whisker movements.

Animals were killed $1,2,4,8,12$, and $18 \mathrm{~d}$ p.o. Brain stems were dissected and snapfrozen in liquid nitrogen, and 8- $\mu \mathrm{m}$-thick cryostat sections were cut at the level of the facial nuclei and collected on multiwell glass slides (Nova Kemi, Stockholm, Sweden).

The following fixation and staining procedure was used for visualization of IFN- $\gamma$ immunoreactivity and MHC antigens in nervous tissue. The sections were fixed for $30 \mathrm{sec}$ in ice-cold buffered $2 \%$ formalin, $\mathrm{pH}$ 7.4, briefly washed in PBS, $\mathrm{pH} 7.4$, and subjected thereafter to acetone $\left(-18^{\circ} \mathrm{C}\right)$ for $30 \mathrm{sec}$ followed by washing in PBS for $5 \mathrm{~min}$. The sections were then incubated with $2 \%$ normal horse serum (NHS, Vector Lab., Burlingame, CA) for $30 \mathrm{~min}$. After discarding the NHS, primary mouse monoclonal antibodies diluted in $2 \%$ NHS were applied at concentrations of 3 and $8 \mu \mathrm{g} / \mathrm{ml}$ overnight at $4^{\circ} \mathrm{C}$. The antibodies and their specificities are listed in Table 1.

The DB-1 antibody is a high-affinity antibody directed against the rat IFN- $\gamma$. It inhibits biological effects of IFN- $\gamma$ in vitro (Van der Meide et al., 1986) and in vivo (Jacob et al., 1987). The hybridoma producing DB-1 was provided by Dr. Peter Van der Meide (Primate Centre, TNO, Rijswijk, The Netherlands), and antibodies were purified from culture supernatants in our own laboratory as previously described (Holmdahl et al., 1985). The Ox6, W3/13, W3/25, and Ox19 hybridomas were originally obtained from Dr. Alan Williams (University of Oxford, Oxford, U.K.) and the antibodies purified from culture supernatants in our own laboratory. Ox18, Ox52, and Ox39 were purchased from Sera Lab. (Crawley-Down, U.K.).

After incubation with the MCA, the sections were washed in PBS, and a 1:30 dilution of biotinylated horse anti-mouse IgG (Vector Lab.) was applied for $1 \mathrm{hr}$, followed by washing. This reagent had been crossabsorbed to rat immunoglobulin and was further diluted in $2 \%$ normal rat serum. Avidin-biotin-peroxidase complex was then applied (ABC Vectastain kit, Vector Lab.) for $1 \mathrm{hr}$ followed by staining for peroxidase with 3-amino-9-ethylcarbazole (Sigma, USA) as substrate (Kaplow, 1974).

In control sections the primary antibody was omitted. The series of antibodies not directed against IFN- $\gamma$ and MHC antigens partly served as irrelevant control antibodies.

The stained sections were coded, and the distribution of reaction product was assessed light microscopically in the left facial nuclei, also 


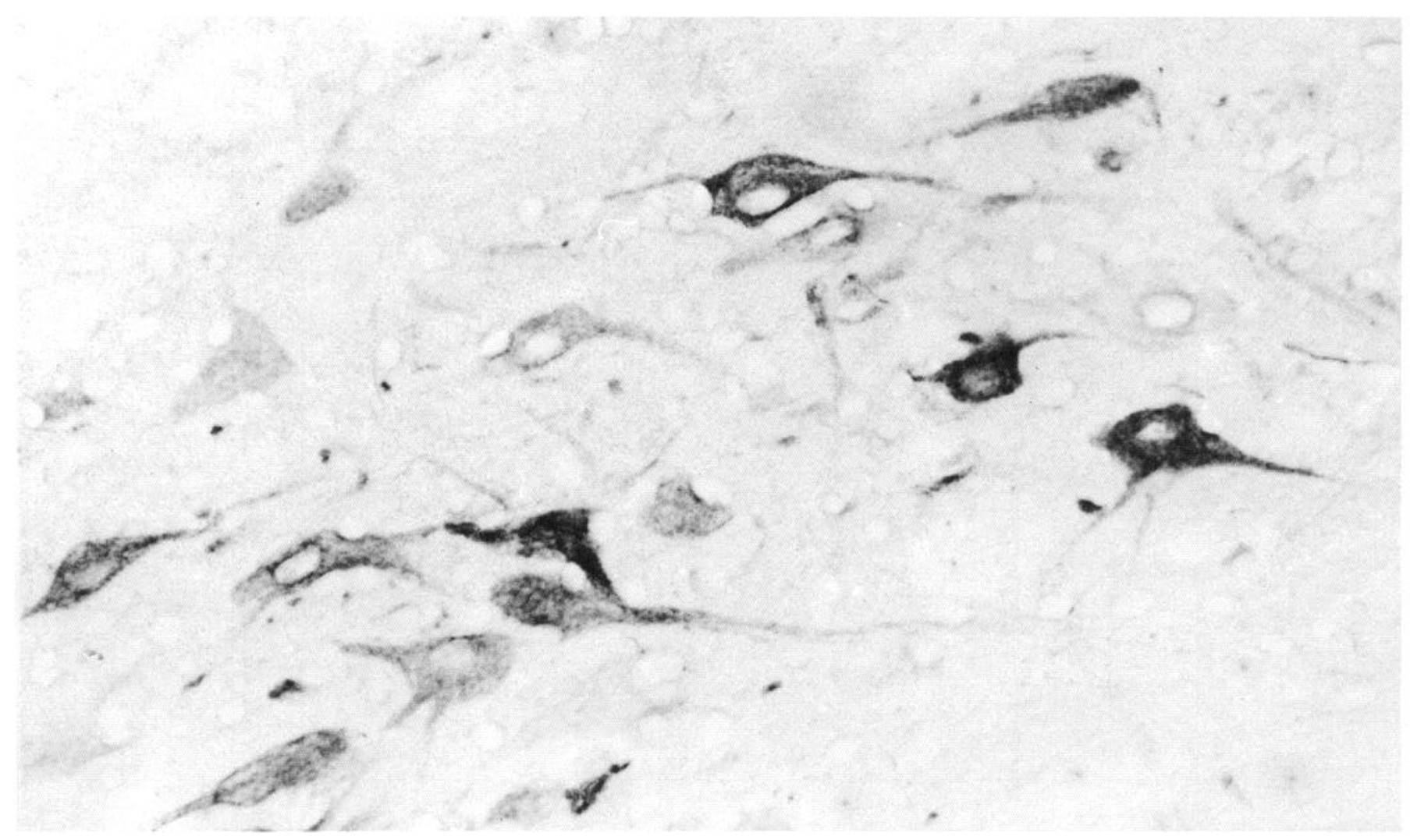

Figure 1. Neurons with IFN- $\gamma$-like immunoreactivity in the cytoplasm, $4 \mathrm{~d}$ after crushing the facial nerve. $\times 360$.

allowing comparison in the same section with the right nonlesioned facial nuclei.

\section{Results}

IFN- $\gamma$-like immunoreactivity

IFN- $\gamma$-like immunoreactivity first appeared day 2 p.o. in animals with both a crush and cut lesion to the facial nerve. The reactivity was much stronger $4 \mathrm{~d}$ p.o. and was seen in the cell bodies of the facial neurons ipsilateral to the lesion but never on the contralateral side. The labeled material had a granular appearance in the perikaryon and dendrites (Fig. 1). In some neurons the staining was more intense in a ring-like fashion around the nucleus. The staining intensity varied between the neurons. The staining was readily apparent with the lowest DB-1 concentration used $(3 \mu \mathrm{g} / \mathrm{ml})$ but stronger with a higher concentration $(8 \mu \mathrm{g} / \mathrm{ml})$. In addition, DB-1 stained many sensory nerve terminals of the trigeminal nerve, as well as varicosities around blood vessels as previously described in the normal brain (Ljungdahl et al., 1989). The IFN- $\gamma$-like immunoreactivity was strong in rats with a nerve crush day 8 p.o. (Fig. $2 a$ ), but on day 12 p.o., no or only a few labeled neurons were seen (Fig. $2 c$ ). In contrast, in rats with cut lesions of the nerve, the DB-1 staining was still present on days 12 and 18 p.o. (Fig. $3 a$ ). Sections in which the primary antibody had been omitted were always negative.

\section{MHC immunoreactivity}

MHC class I immunoreactivity, as detected with the Ox18 antibody, first appeared in and around ipsilateral motor neurons day 2 p.o. The distribution of this staining differed from that of DB-1. There was a finely granular staining of the nerve cell cytoplasm. This staining was much more intense along the neuronal surface. There was also a staining of non-neural cells outlining the neurons, as judged by small cell nuclei "buried" within reaction product (Fig. $2 b$ ). In crush-lesioned rats, the staining had subsided after day 12 p.o. (Fig. $2 d$ ), whereas it persisted in animals with cut lesions (Fig. $3 b$ ).

Class II antigen immunoreactivity as detected by the Ox6 antibody appeared on day 4 p.o. in occasional non-neuronal cells. They were more prominent on day 8 p.o. The labeled cells

Figure 2. Nerve cell bodies $8 \mathrm{~d}(a, b)$ and $12 \mathrm{~d}(c, d)$ after crushing the facial nerve. Many neurons show a strong IFN- $\gamma$-like $(a)$ and MHC class I (b) immunoreactivity $8 \mathrm{~d}$ p.o., but at $12 \mathrm{~d}$ p.o., when reinnervation of the vibrissal muscles had occurred, the IFN- $\gamma$-like immunoreactivity had subsided $(c)$ and the MHC-class I labeling was less pronounced $(d) . \times 180$.

Figure 3. Facial nuclei $18 \mathrm{~d}$ after a nerve transection, when reinnervation of the vibrissal muscles was inhibited, showing the different distributions of the immunoreactivity for IFN- $\gamma(a)$, MHC class I $(b)$ and II $(c)$, and CD4 $(d)$. IFN- $\gamma$-like immunoreactivity has a coarse granular appearance restricted to the cytoplasm and processes of the neurons, while CD4 is confined to non-neuronal cell processes surrounding the negative axotomized neurons. MHC class I is seen both in non-neuronal cells (similar to CD4) and as fine granules in the neural cytoplasm, while MHC class II is confined to some non-neuronal cells in the vicinity of the negative neurons. $\times 380$. 

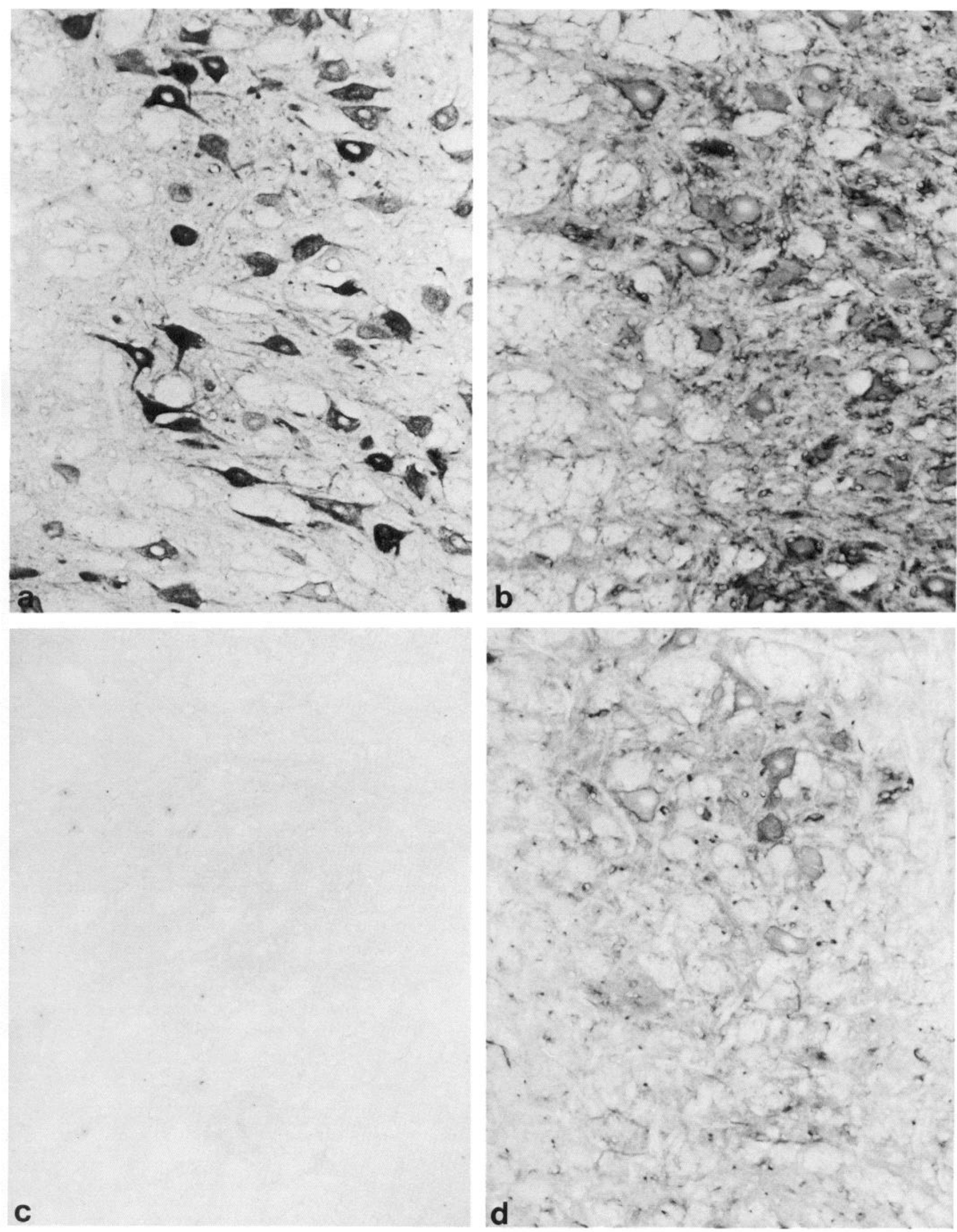


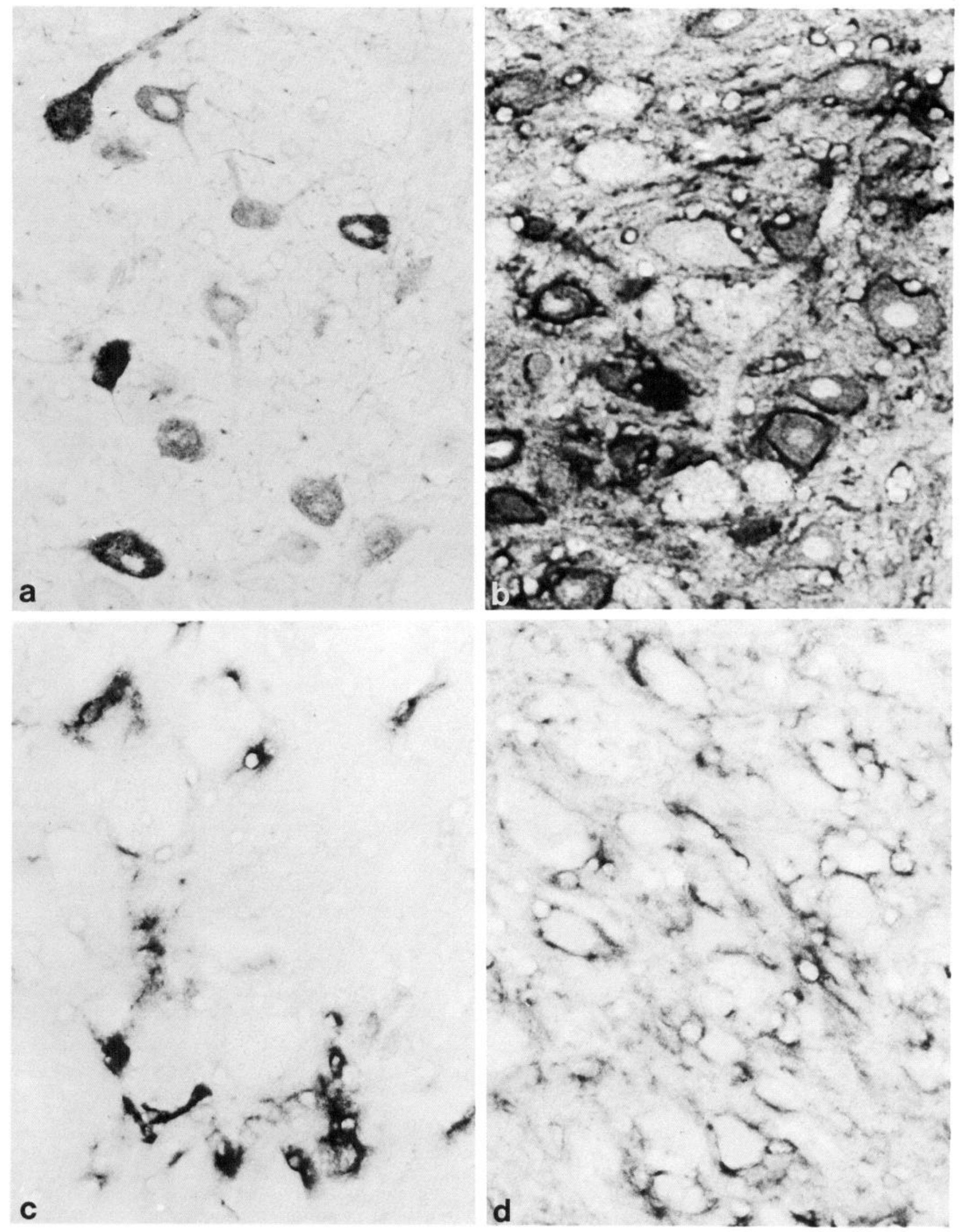




\begin{tabular}{|c|c|c|c|}
\hline $\begin{array}{l}\text { Monoclonal } \\
\text { antibody }\end{array}$ & Specificity & $\mathrm{CD}^{a}$ & Ref. \\
\hline DB1 & Murine IFN- $\gamma$ & & Van der Meide et al., 1986 \\
\hline Ox 18 & MHC class I antigens & & Fukumoto et al., 1982 \\
\hline Ox6 & MHC class II antigens & & McMaster and Williams, 1979 \\
\hline Ox 19 & All $\mathbf{T}$ cells & CD5 & $\begin{array}{l}\text { Mason et al., } 1983 \\
\text { Dallman et al., } 1984\end{array}$ \\
\hline Ox52 & All $T$ cells & & Robinson et al., 1986 \\
\hline W3/13 & All $\mathrm{T}$ cells, leukosialin & & $\begin{array}{l}\text { Brown et al., } 1981 \\
\text { Williams et al., } 1977\end{array}$ \\
\hline W3/25 & $\mathrm{T}$ "helper" cells, some macrophages & CD4 & $\begin{array}{l}\text { Williams et al., } 1977 \\
\text { Barclay, } 1981\end{array}$ \\
\hline Ox39 & Interleukin-2-receptor & & Sedgwick et al., 1987 \\
\hline
\end{tabular}

a Cluster of differentiation according to IUIS/WHO.

with ramified processes were situated close to neurons (Fig. 3c), but an occasional rounded, lymphocyte-like cell and endothelial cells were also stained. The Ox6-stained cells disappeared by day 18 p.o. in rats with a nerve crush, whereas they had increased in number and intensity by day 18 p.o. in rats with a cut lesion.

\section{CD4 immunoreactivity}

CD4 immunoreactivity was detected with the W3/25 antibody. This staining appeared on day 4 p.o. ipsilateral to the axotomy. Reaction product occurred on cells with elongated processes outlining the motor neurons. More cellular processes were stained with this antibody than with the Ox6 antibody and encircled most of the nerve cell body surface (Fig. $3 d$ ). Also in this case the staining had subsided from facial nuclei of animals with a nerve crush day 18 p.o. but persisted in animals with a cut lesion. There was no staining of the nerve cell perikarya.

\section{Immunoreactivity for other lymphocyte surface markers}

The W3/13 stained bouton-like structures around normal motor neurons as described previously (Losy et al., 1989). The staining thus differed markedly from that of IFN- $\gamma$ and MHC antigens. These bouton-like structures disappeared after axotomy but reappeared in rats with a crush lesion $12 \mathrm{~d}$ p.o. Using the other pan T-cell markers, Ox19 and Ox52, no staining was seen in neurons or glial cells. Neither did use of Ox39 result in any staining of neural tissue. However, in the areas of axotomized motor neurons, a few lymphocytes per section, detected by the pan T-cell markers, had regularly appeared $8 \mathrm{~d}$ p.o. No such cells occurred in the contralateral nucleus.

\section{Discussion}

The results show that IFN- $\gamma$-like immunoreactivity appears in the cytoplasm of axotomized motor neurons. This immunoreactivity persists until the nerve is allowed to reinnervate the target muscle. This time course parallels the local appearance of MHC class I and II in axotomized areas (Maehlen et al., $1988,1989 \mathrm{a}, \mathrm{b})$. The induction of these changes, which constitute new features of a nerve cell body's response to axotomy, are probably mediated by signals reaching the perikaryon by retrograde axonal transport, as has been discussed for chromatolysis following axonal lesions (see Kristensson, 1984).

The IFN- $\gamma$-like immunoreactivity is not the result of a nonspecific binding of the immunoreagents to the axotomized neu- rons, since no staining appeared when the primary antibody was omitted, and the other mouse monoclonal antibodies revealed either no staining or a totally different staining pattern. In the normal brain stem and spinal cord, IFN- $\gamma$-like immunoreactivity is present in putative sensory nerve fibers and in various fibers around some blood vessels (Ljungdahl et al., 1989). The monoclonal antibody DB1, which is a high-affinity antibody against rat IFN- $\gamma$, inhibits antiviral effects of IFN- $\gamma$ in vitro (Van der Meide et al., 1986) and affects inflammatory disorders in vivo (Jacob et al., 1987; Strigard et al., 1989). The appearance of a molecule with IFN- $\gamma$-like biological activities in axotomized motor neurons may explain certain phenomena in and around the neurons. IFN- $\gamma$ is the most potent inducer of MHC class I and class II antigens, and it acts in very low concentration. The induction occurs within a few hours (Adams and Hamilton, 1987), and the IFN- $\gamma$-like immunoreactivity seen in the motor neurons on the same day after axotomy as the appearance of MHC class I may therefore indicate a causal relationship. Although IFN- $\gamma$ acts primarily on cell surface receptors, it has also been described that intracellular IFN- $\gamma$ can induce MHC antigen synthesis in a cell (Sancéau et al., 1987). Thus, the expression of the MHC class I antigens in neurons may have been activated in this way. Since IFN- $\gamma$ is a potent macrophage-activating factor (Schultz and Kleinschmidt, 1983; Trinchieri and Perussia, 1985; Adams and Hamilton, 1987; Keller et al., 1987), it may also play a role in inducing the microglial/macrophage reaction which occurs around axotomized neurons (see Graeber et al., 1988; Streit et al., 1988). In particular, it is interesting to note the induction of CD4 antigen, which, in contrast to MHC class I antigen, was restricted to the non-neuronal cells. Recently, an induction of CD4 antigen in Langerhans cells in the gingiva has been reported after exposure to IFN- $\gamma$ (Walsh et al., 1987). The appearance of a neuronally derived IFN- $\gamma$-like molecule may also explain why experimental allergic encephalomyelitis is enhanced around axotomized neurons in the spinal cord and brain stem (Maehlen et al., 1989b).

After an axon lesion, the nerve cell metabolism changes from synthesis of transmitter-related enzymes to production of substances involved in regeneration of new axonal processes (see Watson, 1974; Torvik, 1976; Willard and Skene, 1982). IFN- $\gamma$ represents a cytokine that can regulate a cell's protein synthesis. For example, in macrophages it induces mRNA for a series of polypeptides, e.g., IL-1, tumor necrosis factor, and urokinase 
genes, and reduces transcription of certain other genes (Collart et al., 1986). A molecule with IFN- $\gamma$-like immunoreactivity induced in axotomized motor neurons may therefore serve important functions in regulating the molecular events both in the neuron and in its surroundings during regeneration.

\section{References}

Adams, D. O., and T. A. Hamilton (1987) Molecular transductional mechanisms by which IFNgamma and other signals regulate macrophage development. Immunol. Rev. 97: 5-27.

Barclay, A. N. (1981) The localization of populations of T lymphocytes defined by monoclonal antibodies in rat lymphoid tissues. Immunology 42: 593-600.

Brown, W. R. A., A. N. Barclay, C. A. Sunderland, and A. F. Williams (1981) Identification of a glycophorin-like molecule at the cell surface of rat thymocytcs. Nature 289: 456-460.

Collart, M. A., D. Belin, J.-D. Vassalli, S. de Kossodo, and P. Vassalli (1986) Gammainterferon enhances macrophage transcription of the tumor necrosis factor/cachectin, interleukin 1, and urokinase genes, which are controlled by short-lived repressors. J. Exp. Med. 164: 2113-2118.

Dallman, M. J., M. L. Thomas, and J. R. Green (1984) A monoclonal antibody that labels rat $\mathrm{T}$ lymphocytes and augments in vitro proliferative responses. Eur. J. Immunol. 14: 260-267.

Fukumoto, T., W. R. McMaster, and A. F. Williams (1982) Mouse monoclonal antibodies against rat major histocompatibility antigens. Two Ia antigens and expression of Ia and class I antigens in rat thymus. Eur. J. Immunol. 12: 237-243.

Giulian, D., D. G. Young, J. Woodward, D. C. Brown, and L. B. Lachman (1988) Interleukin-1 is an astroglial growth factor in the developing brain. J. Neurosci. 8: 709-714.

Graeber, M. M., W. J. Streit, and G. W. Kreutzberg (1988) Axotomy of the rat facial nerve leads to increased CD3 complement receptor expression by activated microglial cells. J. Neurosci. Res. 21: 18-24.

Holmdahl, R., T. Olsson, T. Moran, and L. Klareskog (1985) In vivo treatment of rats with monoclonal anti- $\mathrm{C}$-cell antibodies. Immunohistochemical and functional analysis in normal rats and experimental allergic neuritis. Scand. J. Immunol. 22: 157-169.

Jacob, O. O., P. H. Van der Meide, and H. O. McDevitt (1987) In vitro treatment of $(\mathrm{NZB}+\mathrm{NZW}) \mathrm{F}$ lupus-like nephritis with monoclonal antibody to interferon. J. Fxp. Med. 166: 798-803.

Kaplow, L. S. (1974) Substitute for benzidine in myeloperoxidase stains. Am. J. Clin. Pathol. 63: 451.

Keller, R., R. Keist, P. H. Van der Meide, P. Groscurth, M. Auget, and P. Leist (1987) Induction, maintenance, and reinduction of tumorical activity in bone marrow-derived mononuclear phagocytes by Corynebacterium parvurn. J. Immunol. 138: 2366-2372.

Kristensson, K. (1984) Retrograde signaling after nerve injury. In Axonal Transport in Neuronal Growth and Regeneration, J. S. Elam and P. Cancalon, eds., pp. 31-43, Plenum, New York.

Lampson, L. A. (1987) Molecular basis of the immune response to neural antigens. Trends Neurosci. 10: 211-216.

Ljungdahl, §., T. Olsson, P. H. Van der Meide, R. Holmdahl, L. Klareskog, and B. Höjeberg (1989) Interferon-gamma-like immunoreactivity in certain neurons of the ventral and peripheral nervous system. J. Neurosci. Res. (in press).

Losy, J., J. Maehlen, T. Olsson, and K. Kristensson (1989) Distribution of leukosialin (W3/13)-like immunoreactivity in the rat central nervous system. J. Neurocytol. 18: 71-76.

Maehlen, J., H. Daa Schröder, L. Klareskog, T. Olsson, and K. Kristensson (1988) Axotomy induces MHC class I antigen expression on rat nerve cells. Neurosci. Lett. 92: 8-13.

Maehlen, J., I. Nennesmo, A.-B. Olsson, T. Olsson, H. Daa Schröder, and K. Kristensson (1989a) Peripheral nerve injury causes transient expression of MHC class I antigens in rat motor neurons and skeletal muscles. Brain Res. 481: 368-372.

Maehlen, J., T. Olsson, A. Zachau, L. Klareskog, and K. Kristensson (1989b) Local enhancement of MHC class I and II expression and cell infiltration in experimental allergic encephalomyelitis around axotomized motor neurons. J. Neuroimmunol. 23: 125-132.

Mason, D. W., R. P. Arthur, M. J. Dallman, J. R. Green, G. D. Spickett, and M. L. Thomas (1983) Functions of rat T lymphocyte subsets isolated by means of monoclonal antibodies. Immunol. Rev. 74: 5782.

McMaster, W. R., and A. F. Williams (1979) Identification of Ia glycoproteins in rat thymus and purification from rat spleen. Eur. J. Immunol. 9: 426-433.

Nakamura, M., I. Manser, G. D. N. Pearson, M. J. Daley, and M. L. Gefter (1984) Effect of IFN- $\gamma$ on the immune response in vivo and on gene expression in vitro. Nature 307: 381-382.

Olsson, T., I. Forsberg, and K. Kristensson (1978) Uptake and retrograde axonal transport of horseradish peroxidase in regenerating facial motor neurons of the mouse. J. Neurocytol. 7: 323-336.

Robinson, A. P., M. Puklanec, and D. W. Mason (1986) MRC Ox52: A rat $\mathrm{T}$ cell antigen. Immunology 57: 527-531.

Rosa, F., and M. Fellous (1984) The effect of gammainterferon on MHC antigens. Immunol. Today 5: 261-262.

Sancéau, J., P. Sondermeyer, F. Béranger, R. Falcoff, and C. Vaquero (1987) Intracellular human $\gamma$-interferon triggers an antiviral state in transformed murine L cells. Proc. Natl. Acad. Sci. USA 84: 29062910.

Sandvig, S., T. Lasbay, J. Andersson, M. De Ley, and A. Andersson (1987) Gamma-interferon is produced by CD3+ and CD3 - lymphocytes. Immunol. Rev. 97: 51-65.

Schultz, R. M., and W. J. Kleinschmidt (1983) Functional identity between murine gamma interferon and macrophage activating factor. Nature 305: 239-240.

Sedgwick, J., S. Brostoff, and D. Mason (1987) Experimental allergic encephalomyelitis in the absence of a classical delayed-type hypersensitivity reaction. J. Exp. Med. 165: 1058-1075.

Skoskiewicz, M. J., R. B. Calvin, E. E. Schneeberger, and P. S. Russel (1985) Widespread and selective induction of major histocompatibility complex determined antigens in vivo by gammainterferon. $\mathbf{J}$. Exp. Med. 162: 1645-1664.

Streit, W. J., M. B. Graeber, and G. W. Kreutzberg (1988) Functional plasticity of microglia: A review. Glia 1: 301-307.

Strigård, K., R. Holmdahl, P. Van der Meide, L. Klareskog, and T. Olsson (1989) In vivo treatment of rats with monoclonal antibodies against gamma-interferon: Effects on experimental allergic neuritis. Acta Neurol. Scand. (in press)

Tirone, F., and E. M. Shooter (1989) Early gene regulation by nerve growth factor in PC12 cells: Induction of an interferon-related gene. Proc. Natl. Acad. Sci. USA 86: 2088-2092.

Torvik, A. (1976) Central chromatolysis and the axon reaction: A reappraisal. Neuropathol. Appl. Neurobiol. 2: 423-432.

Trinchieri, G., and B. Perussia (1985) Immune interferon: A pleotropic lymphokine with multiple effects. Immunol. Today 6: 131-136.

Van der Meide, P. H., M. Dubbeld, K. Vijerberg, T. Kos, and H. Schellekens (1986) The purification and characterization of rat gamma interferon by use of two monoclonal antibodies. J. Gen. Virol. 67: 1059-1071.

Wallach, D., M. Fellous, and M. Revel (1982) Preferential effects of gammainterferon on the synthesis of HLA antigens and their mRNAs in human cells. Nature 299: 883-886.

Walsh, L. I., A. Parry, A. Scholes, and G. J. Seymour (1987) Modulation of CD4 antigen expression on human gingival Langerhans cells by gamma interferon. Clin. Exp. Immunol. 70: 379-385.

Watson, W. E. (1974) Cellular responses to axotomy and related procedures. Br. Med. Bull. 30: 112-115.

Willard, M., and J. H. P. Skene (1982) Molecular events in axonal regeneration. In Repair and Regeneration of the Nervous System, $\mathbf{J}$. G. Nicholls, ed., pp. 71-89, Springer-Verlag, New York.

Williams, A. F., G. Gallfre, and C. Milstein (1977) Analysis of cell surfaces by xenogenic myeloma hybrid antibodies: Differentiation antigens of rat lymphocytes. Cell 12: 663-673.

Wong, G. H. W., P. F. Bartlett, S. Clark-Lewis, F. Baltye, and J. W. Schrader (1984) Inducible expression of $\mathrm{H}-2$ and Ia antigen on brain cells. Nature 310: 688-691. 